November - 2004

\title{
Group and Class Contexts for Learning and Support Online: Learning and affective support online in small group and class contexts
}

\author{
Bill Anderson and Mary Simpson \\ Massey University \\ New Zealand
}

\begin{abstract}
This study was designed to evaluate the use of asynchronous discussion in distance education in terms of student perceptions of its value for learning and for affective support. At the end of the third and sixth years of a distance delivered teacher education programme, students completed a survey to determine the extent to which the nature and characteristics of the online aspects of the programme contributed to learning and afforded affective support. Students perceived considerable value in the online interaction for both learning and support. Small groups and the whole class were seen as the dominant spaces for interaction, but there was considerable differentiation between them in terms of their contribution to affective support. The small group discussions were seen as most important for all aspects of communication but students reported non-participation by some members as a significant problem.
\end{abstract}

Keywords: online learning; interaction; group discussion; student support; distance education; asynchronous communication

\section{Learning and Affective Support Online in Small Group and Class Contexts}

At the heart of a group of learners lies the communication that takes place between its members. That communication serves two main functions. In the broad terms that Gee (1999, p. 1) uses discussing language, those functions are "to scaffold the performance of social activities (whether play or work or both) and to scaffold human affiliation within cultures and social groups and institutions." In more specific terms relevant to online learning communities, the functions can be described for the student community members as scaffolding the attainment of the goals of their study, and scaffolding affective support for each other (Anderson, 2004; Pavitt and Johnston, 1999).

This paper will discuss the way in which students perceive these two functions of the interaction between learners in an online learning environment. Discussion focuses on the use of asynchronous interaction within a distance delivered teacher education programme, emphasising the way in which students perceived the characteristics of their interaction and the value it had for their learning and affective support in the programme. A particular feature is that students 
engaged in the interaction in both small groups and whole class settings, providing the opportunity to examine the perceptions of interaction within each setting.

\section{A Communication Infrastructure for Learning and Support}

Attrition rates among distance students are high in comparison to students undertaking traditional face-to-face study (Ryan, 2001). A solution to the issue of student attrition is to emphasise the social and community aspects of student life. Thus an intentional aim for the online interaction of students in a programme must be the development of a culture of support and care (Wrightson, 1998). Yorke (2004) argues that students who feel part of a community are less likely to drop out than those who feel alone, but states that developing a sense of belonging "is a particular challenge when the student is remote from the provider” (p. 26).

When students are remote, online communication provides an effective means of drawing students together to develop a sense of community. Rovai (2002) argues that communities can develop amongst groups of online learners and that they are characterized by "feelings of connectedness among community members and commonality of learning expectations and goals" (p. 322).

The size of the community has a direct bearing on the extent to which all involved have a sense of belonging. Within any community, as the number of people involved increases directly, the number of potential linkages between them increases at a much greater rate. Fahy, Crawford and Ally (2001) note that group size becomes a determinant of the level of involvement, and thus sense of belonging. Smaller groups could expect to develop closer relationships.

Developing a communication infrastructure for a full time distance delivered programme raises design questions over and above those faced in the design of individual courses. Programme goals as well as individual course objectives must be considered, meaning that the particular demands of the area of the programme will be an additional focus for the design. With an emphasis on teacher education, a second aim of providing an infrastructure for interaction online must be to enable sharing, discussion, and synthesis and integration of theoretical perspectives and practical experiences as a contributing factor in the development of critical reflection on practice. The centrality of critical reflection to a teacher education programme is such that the design of the programme must afford all students the greatest opportunity possible to engage in the higher order dialogic activities that support such reflection.

A number of studies on the quality of online interaction report that within online discussion forums there is extensive interaction involving giving of information and exploration of ideas, but considerably less interaction in support of integration of ideas and resolution of divergent themes (e.g., Angeli, Valanides and Bonk, 2003; Fahy, Crawford and Ally, 2001; Garrison, Anderson and Archer, 2001; Gunawardena, Lowe and Anderson, 1997). However, Howell-Richardson and Mellar (1996) and Garrison (2001) provide evidence to support the view that patterns of interaction are likely to be determined by the instructional design (course material should focus on synthesis of ideas and concepts) and moderation of discussion (moderators should guide discussion toward higher-order cognitive activities). In addition, drawing on the discussion of Fahy, Crawford and Ally, it is suggested that work in small groups enhances opportunities for engagement leading to greater possibilities for integration and synthesis of a range of perspectives. 


\section{Context of the Study}

The online interaction that is the focus of this study took place amongst students in a full-time three-year programme of distance study leading to the award of the Bachelor of Education (Teaching) degree. The programme consists of four strands - education foundations, professional inquiry and practice, curriculum study, and studies in subjects.

The programme must be regarded as small scale in distance education terms. The first intake was limited to 50 students. Subsequent annual intakes have all been less than 100 students, and there are currently just over 200 students enrolled, most of whom are full time students moving through the programme in cohort groups. Although student numbers are small, the predominantly full time nature of study means that students acquire considerable experience as online students. In the three years it takes to complete the programme as a full-time student, each student will have to pass 24 courses at a distance, where all courses have a compulsory, but un-graded requirement of regular participation in discussion tasks. In addition, some courses require involvement in collaborative assessment tasks online.

The programme is not entirely online. Students receive print material and digital and practical resources at the beginning of each semester. A learning management system (WebCT) is used to enable online communication and some content delivery and self-assessment activity. Students are not required to go on campus at any stage of the programme.

As an indicator of engagement in the online component, message count data was obtained during the first three years of the programme. The following table represents the average number of messages that a student and a lecturer would expect to receive each week for each of the semesters of the first three years. These averages only relate to communication using the Bulletin Board feature of WebCT, and do not include personal communication between students and between lecturers and students (using WebCT's Private Mail function).

Table 1. Average number of messages received per week over a sixteen week semester

\begin{tabular}{|c|c|c|c|c|c|c|}
\hline & \multicolumn{2}{|c|}{$\begin{array}{l}\text { First year of } \\
\text { programme }\end{array}$} & \multicolumn{2}{|c|}{$\begin{array}{l}\text { Second year of } \\
\text { programme }\end{array}$} & \multicolumn{2}{|c|}{$\begin{array}{l}\text { Third year of } \\
\text { programme }\end{array}$} \\
\hline & $\begin{array}{l}\text { Semester } \\
1\end{array}$ & $\begin{array}{l}\text { Semester } \\
2\end{array}$ & $\begin{array}{l}\text { Semester } \\
1\end{array}$ & $\begin{array}{l}\text { Semester } \\
2\end{array}$ & $\begin{array}{l}\text { Semester } \\
1\end{array}$ & $\begin{array}{l}\text { Semester } \\
2\end{array}$ \\
\hline $\begin{array}{l}\text { First year } \\
\text { students }\end{array}$ & $157(52)$ & 105 & $125(73)$ & 118 & $145(70)$ & 224 \\
\hline $\begin{array}{l}\text { Lecturers (of } \\
1^{\text {st }} \text { year } \\
\text { students) }\end{array}$ & 28 & 15 & 27 & 25 & 29 & 43 \\
\hline $\begin{array}{l}\text { Second year } \\
\text { students }\end{array}$ & & & $148(48)$ & 148 & $125(65)$ & 90 \\
\hline $\begin{array}{l}\text { Lecturers (of } \\
2^{\text {nd }} \text { year } \\
\text { students) }\end{array}$ & & & 23 & 20 & 22 & 22 \\
\hline $\begin{array}{l}\text { Third year } \\
\text { students }\end{array}$ & & & & & $117(46)$ & 98 \\
\hline $\begin{array}{l}\text { Lecturers } \\
\text { (of 3rd year } \\
\text { students) }\end{array}$ & & & & & 36 & 35 \\
\hline
\end{tabular}


Each course in the programme has its own WebCT site and within that a bulletin board structure that enables small group and whole class discussion. The programme was designed to take advantage of the inherent closeness and supportive nature of small groups. Study guides for each course contain activities that the students are required to undertake and discuss online. Activities are typically written to encourage initial discussion online in small groups of five to eight members. These groups have common membership, or a core of common membership such that students work together in the same small group across all courses in their cohort. Following small group online discussion, groups report to a whole class forum and additional class-wide discussion occurs there. A guideline for the programme is that in each course, students should make at least three substantive contributions to discussion each week in either small group or class forums. Substantive is described in terms of Anderson and Garrison's (1998) discussion of online interaction.

Teaching in a class requires lecturers to take sections of 30 - 35 students, and in most instances students see themselves as being in a "whole class" of that size. A few lecturers teaching more than one section combine their sections to form a whole class of 60 - 70 students. Lecturers lead or facilitate discussion in the whole class forums in contrast with the small groups discussions that are collaborative (Bonk and Cunningham, 1998; Bruffee, 1999), student led and have minimal lecturer involvement. Teaching throughout the programme follows a broadly constructivist approach (Jonassen, Davidson, Collins, and Bannan Haag, 1995).

All students in the programme are required to participate in an online discussion for every course in which they are enrolled as a part of their programme of study. This means that most students are engaged in four or five different course-based discussions with the same small group each semester. Composition of the small groups, which are formed at random, changes each year.

\section{Purpose and Method of the Study}

An end-of-year survey was undertaken in each of the first three years of the programme, and again after it had been running for six years, to determine the extent to which the online infrastructure and interaction were addressing the goals set out for them. The survey focused on the extent to which students perceived the nature and characteristics of the online aspects of the programme contributing to their learning and affording affective support. Data from the last two surveys undertaken (the third year and the sixth year surveys) are reported here.

Survey items remained relatively unchanged across the surveys, although some new items were added to the survey and a small number removed. Each survey gathered some base data such as estimates of hours studied per week, cost of online access, location and age range of student, and earlier surveys also reported quantitative measures of student interaction online. Each survey also asked students to complete a number of 5-point Likert scale items (strongly agree; slightly agree; neutral; slightly disagree; strongly disagree) related to the following four areas: interaction and collaboration online; lecturer's role; social presence and affective support; and the use of online tools. In addition, the survey asked students to rank the various modes of online communication in order of importance to them for learning and for affective support.

The numerical data reported below from the latest (sixth year) survey are accurate to a $+/-5$ percent interval at the 95 percent level of confidence. All students $(n=216)$ in the programme were surveyed, with a response rate of 61 percent. Results from the third year survey, which had a response rate of 75 percent of the total population $(n=130)$, are added for comparative purposes where items were present in both surveys. Students were also invited to add comments in relation 
to any of the items in the survey. Comments from the sixth year survey are reported here; 106 of the 132 survey respondents added comments to their survey. Comments were collated and analysed thematically, based on the broad themes of the survey.

The survey data are used here in the discussion of two points of particular importance in the study of contexts for online interaction. We first discuss student perceptions of several aspects of interaction for learning online, and then report on and discuss student responses to the fewer items concerning affective support. Running through this discussion is a thread that teases out the impact of small groups in contrast with whole class interaction.

\section{Interaction for Learning}

This section presents and discusses survey results relating to student perceptions of their online interaction for learning. The text in the Item column of each table is the exact text used in the survey items.

An initial issue is the extent to which the design of courses and the moderation of lecturers were perceived by students as making available opportunities for interaction. Table 1 shows how students saw this design aspect of the programme as affording the possibilities for involvement. For this table, and all others, the percentage in overall agreement indicates the sum of the percentage of participants reporting strong agreement, and the percentage of participants reporting slight agreement with the item.

Table 2. Designing for interaction

\begin{tabular}{|c|c|c|c|c|}
\hline \multirow[t]{2}{*}{ Item } & \multicolumn{2}{|c|}{$\begin{array}{l}\text { Strong } \\
\text { agreement }(\%)\end{array}$} & \multicolumn{2}{|c|}{$\begin{array}{l}\text { Overall } \\
\text { agreement }(\%)\end{array}$} \\
\hline & $\begin{array}{l}6-\mathrm{yr} \\
\text { Survey }\end{array}$ & $\begin{array}{l}3-\mathrm{yr} \\
\text { Survey }\end{array}$ & $\begin{array}{l}\text { 6-yr } \\
\text { Survey }\end{array}$ & $\begin{array}{l}\text { 3-yr } \\
\text { Survey }\end{array}$ \\
\hline $\begin{array}{l}\text { Many opportunities for learning collaborations } \\
\text { with others were built into the course material. } \\
\text { (11) }\end{array}$ & 53 & 44 & 89 & 92 \\
\hline $\begin{array}{l}\text { Lecturers often led discussions in the class } \\
\text { discussion groups. } \\
\text { (e.g, by stating a topic and prowiding a lead } \\
\text { question, by sating limits to the discussion or } \\
\text { by winding up discussion of a topic) (15) }\end{array}$ & 35 & 44 & 75 & 82 \\
\hline $\begin{array}{l}\text { Lecturers often facilitated discussions on class } \\
\text { discussion groups. } \\
\text { (e.g, by questioning student responses or } \\
\text { picking themes from small group discussions } \\
\text { and expanding them) (16) }\end{array}$ & 26 & 31 & 69 & 71 \\
\hline
\end{tabular}

The first item in Table 1 shows that students reported recognising the opportunities for learning collaborations with others that were built into course material. The increase in strong agreement from the third to the sixth year survey, can be taken as reflecting the ongoing institutionally-based quality improvement processes that focus on material development. The continuing extremely high level of overall agreement indicates that the course material provided remains, for all students, a means through which they can enter into online interaction. Comments by two 
students on this item suggested an uneven picture, with interaction opportunities being built into some courses more than others $(46,11 ; 6,11)$ while several others indicated that issues lay more in ensuring members contributed to discussion than in providing opportunities for interaction. (Notation indicates Participant Number and Question Number; thus $(46,11)$ means Participant 46 made this comment adjacent to Question 11.) Typical here were comments that: "Opportunities were there, but often classmates weren't." $(36,11)$ and "But don't agree that they are always effective if there is a dysfunctional group” $(114,11)$. These latter comments signal issues concerning the use of small groups that are discussed later in this paper.

Students perceive the role of lecturing staff within whole class discussions as being more directive than facilitative. The decline in agreement seen in both items suggests perhaps that lecturers are to some extent withdrawing from engagement at the whole class level. Seventeen of the respondents commented about this item, many noting again the variability across courses. The comment "It really depended on the subject/ lecturer as to how/ if they led discussions. Some subject lecturers were fabulous at this and others were barely present" $(16,15)$, encapsulates this type of response.

Acknowledging opportunities for engagement and collaboration is the first step; students must then actively engage in interaction. They report taking advantage of those opportunities and going beyond their own perspectives as they do so.

Table 3. Usefulness of Interaction for Leaming

\begin{tabular}{|c|c|c|c|c|}
\hline \multirow[t]{2}{*}{ Item } & \multicolumn{2}{|c|}{$\begin{array}{l}\text { Strong } \\
\text { agreement }(\%)\end{array}$} & \multicolumn{2}{|c|}{$\begin{array}{l}\text { Overall } \\
\text { agreement }(\%)\end{array}$} \\
\hline & $\begin{array}{l}6-\mathrm{yr} \\
\text { Survey }\end{array}$ & $\begin{array}{l}\text { 3-yr } \\
\text { Survey }\end{array}$ & $\begin{array}{l}6-\mathrm{yr} \\
\text { Survey }\end{array}$ & $\begin{array}{l}\text { 3-yr } \\
\text { Survey }\end{array}$ \\
\hline $\begin{array}{l}\text { I often became involved in collaboration with } \\
\text { other students for learning in the course (12) }\end{array}$ & 49 & 42 & 83 & 85 \\
\hline $\begin{array}{l}\text { Other students often shared their understanding } \\
\text { of the course topics with me (19) }\end{array}$ & 27 & 40 & 77 & 81 \\
\hline $\begin{array}{l}\text { Online collaborations with others provided me } \\
\text { with points of view about course material that I } \\
\text { might not have othewise considered (13) }\end{array}$ & 52 & 60 & 82 & 91 \\
\hline
\end{tabular}

The figures in Table 3 show a high level of overall agreement about the existence of collaboration in the course. Of most importance is the response to the third of these items, showing that a majority of students are in strong agreement that, through collaboration with others, they were exposed to new points of view about the concepts and ideas expressed in course material. For the second item, the low level of strong agreement in the six-year survey can be teased out through consideration of the different responses of students in each year group. Students in their first year of study had a low level of strong agreement with this item (21 percent), while 34 percent of students in their third year of study report strong agreement. It is not surprising to find that as students become more accustom to working with each other, they become more willing to share ideas and understandings.

These figures are supported by the comments that students added to their survey response sheet. The high levels of overall agreement reported above are reflected in the generally positive 
comments students made about their interaction online. In a typical comment, a student reported finding ". . . that by discussing online, I was able to gain further understandings of course content and clarify my own ideas with others” $(1,42)$. Question 42 asked for additional comments about the effectiveness or limitations of online delivery. The comments were effectively summarised in the response of one student who noted:

\section{Value}

- New insights/ clarification from others

- Forces you to participate and not go it alone in isolation

- Forces you to acknowledge your misunderstandings

- Get feedback on whether you're on the right track or not

\section{Strengths}

- When others in group are committed, real partnership in learning is felt

- $\quad$ Encourages climate of learning $(110,42)$

Collaboration online is not without its tensions, even within the picture of success that the survey results and comments above provide. The small group nature of much of the work is dependent on all students participating. If two people in a group of seven decide not to participate, the number of potential linkages halves, dramatically reducing the extent to which the work that is required to be undertaken can be shared, perspectives developed, and ideas critiqued. In addition, prior online friendships affect the social balance of a group; the asynchronicity of the work can disrupt problem-solving discussion; and all the while the permanence of the text-based discussion leaves a trail of intellectual endeavour for the non-participant to absorb.

The delivery of the courses about which the participants are commenting, is best described as paced asynchronous delivery. While students are free to work in their own time and to contribute to discussion at their own pace, the discussions themselves are set to a specific schedule. Typically discussions in a course will last for 7 - 10 days before a move is made to a new topic. Students are expected to make a contribution to the discussion during the time when that discussion is active.

Paced delivery has not diluted a strength of asynchronous courses - that students can take the time to reflect on others' comments before responding. Tension arises, however, because each discussion has to move at a reasonable pace to enable adequate exchange, synthesis, and integration of ideas in the time allotted. While students reported taking time to reflect, they also noted the importance of quick responses to messages along with the difficulty of staying on top of the flow of discussion. The following survey items reflect these points. 
Table 4. Pace of Discussions

\begin{tabular}{|c|c|c|c|c|}
\hline \multirow[t]{2}{*}{ Item } & \multicolumn{2}{|c|}{$\begin{array}{l}\text { Strong } \\
\text { agreement }(\%)\end{array}$} & \multicolumn{2}{|c|}{$\begin{array}{l}\text { Overall } \\
\text { agreement }(\%)\end{array}$} \\
\hline & $\begin{array}{l}6-y r \\
\text { Survey }\end{array}$ & $\begin{array}{l}\text { 3-yr } \\
\text { Survey }\end{array}$ & $\begin{array}{l}6-\mathrm{yr} \\
\text { Survey }\end{array}$ & $\begin{array}{l}\text { 3-yr } \\
\text { Survey }\end{array}$ \\
\hline $\begin{array}{l}\text { I would often spend time reflecting on and } \\
\text { thinking about others' comments before } \\
\text { responding (18) }\end{array}$ & 33 & 35 & 73 & 82 \\
\hline $\begin{array}{l}\text { Online discussions worked best when people } \\
\text { responded quickly to my messages ( } 21 \text { ) }\end{array}$ & 65 & 75 & 89 & 89 \\
\hline $\begin{array}{l}\text { There were many times when it was difficult to } \\
\text { keep up with all the online messages about } \\
\text { course topics ( } 23 \text { ) }\end{array}$ & 35 & 41 & 72 & 69 \\
\hline
\end{tabular}

Table 4 points to a tension in the use of asynchronous online communication. The programme requirement of reflective comment was a good match with the affordances of asynchronous communication. Asynchronous communication, however, also means that the number of messages to be viewed by students, builds up while they are offline, making message reading a lengthy task. In addition, the paced nature of the discussion requires some commitment to timeliness in communication. The tension that exists between reflection and the pace of discussion is also seen in the comments that students make. The discussion provided a "valuable opportunity" $(18,18)$ and reflection on others comments was a case of: "You need to think about things before opening your trap!” $(108,18)$. However, time constraints were clearly signalled, as in: "Often too busy with assignments, and if lots of messages not enough time" $(55,18)$. One student reported "The discussion groups worked well to get to know people however it is difficult to discuss complex issues due to the fact we all organise our work at different times during the week and replies are slow" $(33,42)$, a statement that reflects both the value and the difficulties of a course reliant on asynchronous online communication.

Students developed strategies to deal with the need to respond, with selective reading of messages being the most prominent. They indicated this in statements such as "it becomes easier, as you progress, to notice who it is worth looking into to read, and which clusters of messages to ignore" (116, 23), and: "Just scanned for lecturer's notes/ messages and group members' messages when ultra busy” $(10,23)$.

The survey items reported above do not distinguish between the differing ways in which discussion might occur. This survey sought information about the perceived value to students of the range of ways in which they might pursue online interaction with others in support of their learning. Students were asked to rank seven modes of communication in importance for discussion of or learning about course material, from 1 (most important) to 7 (least important). The modes were: Small discussion groups - small groups of 5 - 8 students; Community site - an informal student only discussion site; Course discussion area - the space for whole class discussion related to a course, with a lecturer and from 25 to 70 students; Online chat rooms synchronous chat facilities; then three categories of person-to-person mail, from a course lecturer, from a fellow student, from the programme's overall coordinator. Where students recorded a mode of communication with a ranking of 1 or 2 it was classified as 'Most important.' Where the communication mode had a ranking of 7 or 8 it was classified as 'Least important.' 
The small group/whole class discussion structure mentioned previously is used in all but one course in the programme. The small discussion groups rank in importance alongside the class discussion that involves lecturers as a favoured mode of interaction for learning. Figure 1 shows the percentage of students who rated these, and other modes of interaction available to them through WebCT, as very important places where learning-enhancing discussion occurred.

Figure 1. Percentage of students identifying a mode of communication as Most Important for learning.

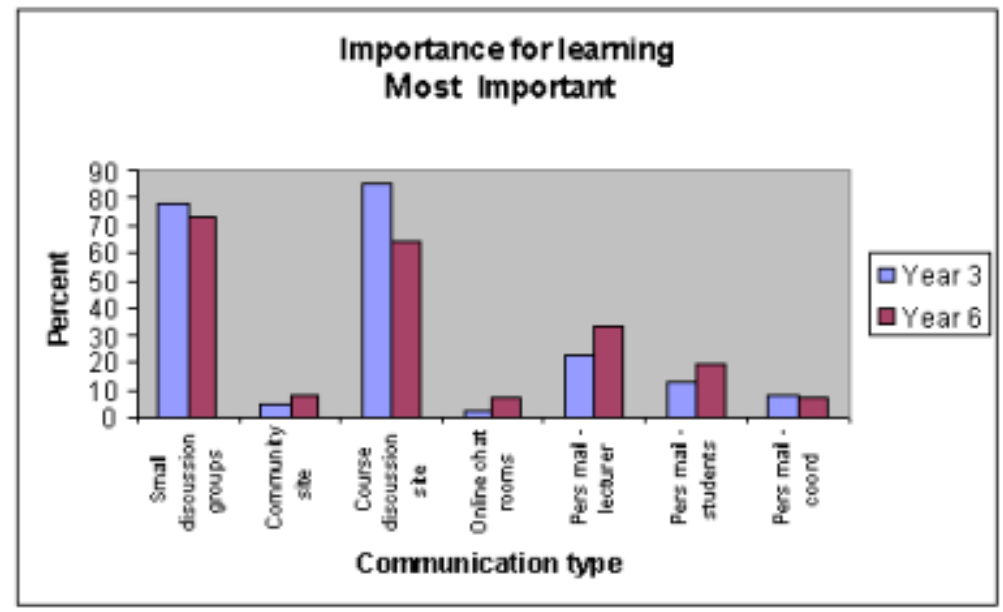

Figure 1 clearly shows that it is exchanges between groups of people, rather than individual exchanges, that students see as being of most importance in their learning. The importance of small groups as sites for learning has stayed remarkably constant across the surveys. The importance of the whole class course discussion site diminished from the third to the sixth year survey. This whole class area is the major site of lecturer involvement in discussion. The decline in importance of this whole class area possibly reflects the decrease in lecturer online presence perceived by students and reported in Table 2 .

We do not suggest that small group discussion is a substitute for whole class discussion. The relative merit of each discussion mode is contingent on the course design. Students clearly see value in both aspects of discussion - a relatively free flowing small group discussion and a more formal lecturer facilitated discussion. Two items from the survey illustrate this. Students were asked to respond to the item: "Online small discussion groups were considerably more useful for my learning than the whole class course discussion site.” Twenty-nine percent of students strongly agreed with the item; overall, 55 percent reported agreement, with only 16 percent reporting disagreement. It should also be noted, however, that 54 percent of students agreed with the item: "More whole class discussion of course topics would be useful" (14 percent disagreed).

\section{Affective Support}

This section presents and discusses survey results relating to student perceptions of the manner in which affective support was part of their online interaction. We have previously discussed the importance of creating feelings of connectedness amongst students at a distance, and developing a 
culture of support and care. The data we present shows the importance of the small groups in making that support available.

To begin, we should note that course material contained no stated or implied expectations about developing online relationships with other students. Responses to one of the survey items confirm that students perceived affective support as one of the outcomes of the online interaction. Seventy six percent of respondents report agreeing with the survey item: "Other EDO students provided affective support for me via online messages." Only 80 percent disagreed. Next we find, unsurprisingly, that students report getting to know their fellow small group students well, in comparison to the whole class of students. Two contrasting items from the survey, shown in Table 3, illustrate this point. Note the high overall agreement with the first item about small groups, and the much-reduced percentage in overall agreement with the second item.

Table 5. Building relationships online

\begin{tabular}{|l|l|l|l|l|}
\hline \multicolumn{1}{|c|}{ Item } & \multicolumn{2}{|l|}{$\begin{array}{l}\text { Strong } \\
\text { agreement (\%) }\end{array}$} & \multicolumn{2}{l|}{$\begin{array}{l}\text { Overall } \\
\text { agreement (\%) }\end{array}$} \\
\hline & $\begin{array}{l}\text { 6-year } \\
\text { survey }\end{array}$ & $\begin{array}{l}\text { 3-year } \\
\text { survey }\end{array}$ & $\begin{array}{l}\text { 6-year } \\
\text { survey }\end{array}$ & $\begin{array}{l}\text { 3-year } \\
\text { survey }\end{array}$ \\
\cline { 2 - 6 } & 41 & 39 & 78 & 83 \\
\hline $\begin{array}{l}\text { I got to know the students in my small discussion } \\
\text { groups well through our small group messages } \\
\text { (25) }\end{array}$ & & 33 & 41 & 47 \\
\hline $\begin{array}{l}\text { I got to know all students in my class group well } \\
\text { through online messages (20) }\end{array}$ & 5 & 31 & & \\
\hline
\end{tabular}

Comments associated with these items, especially the second, stressed the difficulty of getting to know a large number of students online. One student asked: "How the heck are we meant to get to know that many people??? There are some 'out-of-my-group' people who I know, but it's through making an effort to personally meet them and also the types of messages they put online" $(108,26)$, and a second commented: "No way you can get to know all, you would never leave the computer!" $(68,26)$. The sheer number of relationships involved in knowing all class members prohibits full engagement across the entire group.

Figure 2 indicates the importance students place on the different modes of online communication as discussion spaces through which they might receive affective support. Given the results reported above, the distribution of responses comes as no surprise. Students see their small groups as the most important source of affective support within the programme. The procedure for generating Figure 2 is as for Figure 1, except that students were asked to rate the modes of communication in order of importance according to the support and encouragement they received. 
Figure 2. Pexcentage of Students Identifying a Mode of Communication as 'Most Important' for Affective Support

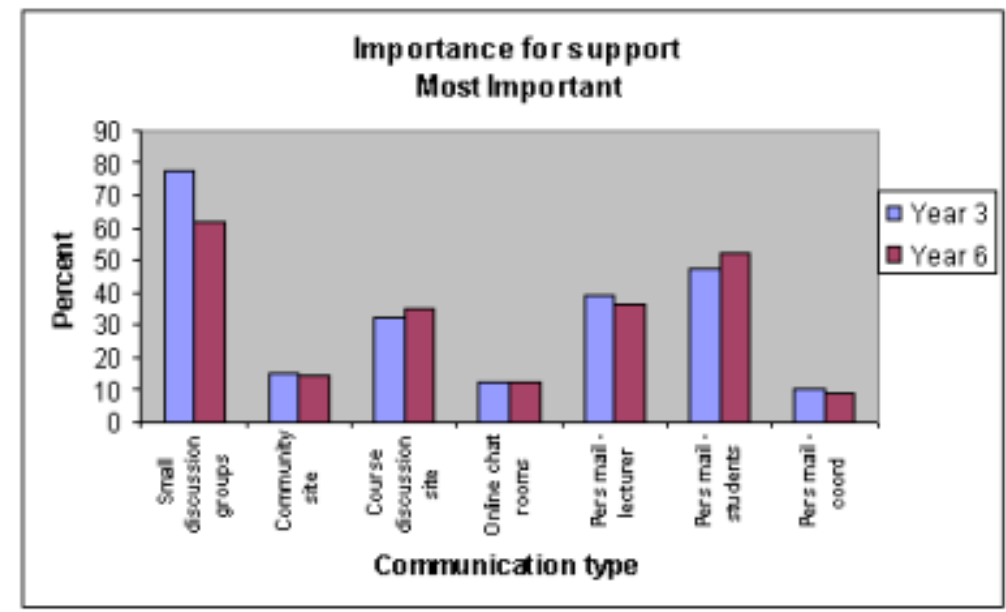

Figure 3 provides a comparison between the levels of importance of the communication modes for learning support and affective support at the six year survey. It reveals three points of interest. Students make clear distinctions between the avenues through which learning support and affective support are provided. Most notable here is the large decrease in the importance of the course discussion site as an avenue for affective support in contrast with its role in support for learning. A second point is the clearly evident increase in the use of personal mail as an avenue for affective support in contrast with its role in support for learning. Finally, this figure clearly identifies the importance of small groups to the students, since those groups feature prominently as sources of learning and affective support. Despite this prominence and importance, students report that the use of small groups was not without problems. The next section addresses some of the issues students reported.

Figure 3. Percentage of Students Identifying a Mode of Communication as "Most Important" for Learning and Affective Support at the Six-year survey.

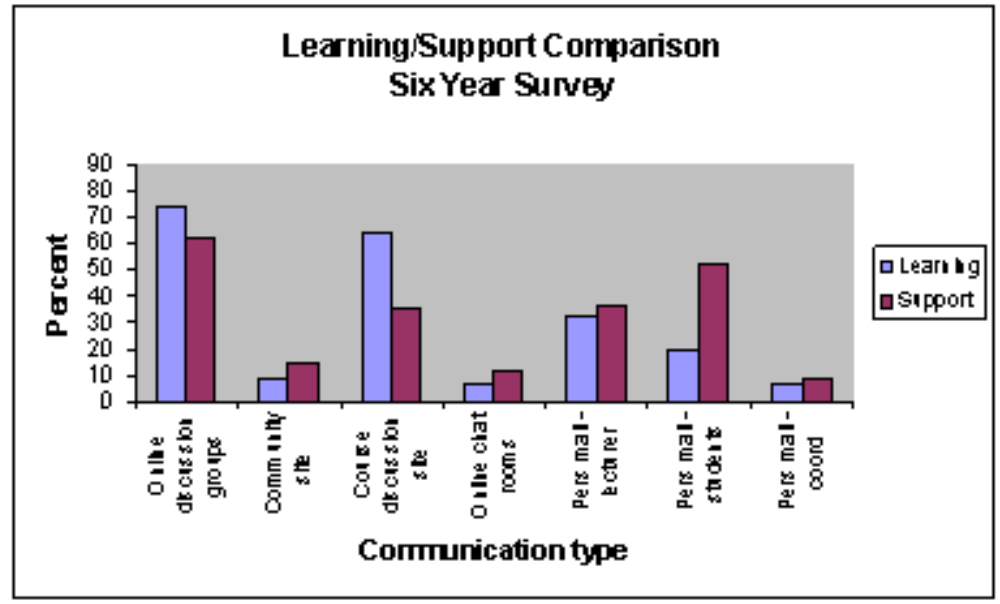




\section{Small Groups Online}

Placing students in small groups with common membership across a range of courses provides the potential for students to develop close intellectually and affectively supportive links. Students made a considerable number of comments about the small group nature of much of the online discussion. To understand their comments here it is useful to know that students will work in a number of small groups during the programme. The ideal will see students working in a different single stable group for all courses in each semester, thus providing them with the opportunity to work with six different sets of five to eight people during their programme. The exigencies of the programme and of student life are such that this ideal is not always realised. A core of members will always be present, but group size and membership can vary from course to course during a semester, and thus students experience some small variation in group contexts.

The value of small groups is reflected in the comments students made within the survey. Comments such as: "Really enjoyed online discussion groups" $(1,42)$ and "the discussion groups have been invaluable during my course" $(112,42)$ are an endorsement of the small group infrastructure. The longevity of the small groups and the extensive experience of small online group processes gained by students during the programme may be a key to the success of the groups. Rose (2004) suggests that collaborative groups with a common history, that are together for more than three weeks, effectively develop high levels of interaction, coordination and shared knowledge.

The data also indicate a concern on the part of some students. The concern that emerges relates to group participation and group dynamics and can be seen in comments such as: "The online discussion groups work excellently when those who are in the group want to be working with others and sharing ideas. At times, sometimes all year, there are groups that don't function because people choose not to participate" $(108,42)$ and: "Discussion groups can work well or, depending on people in them, they can work poorly due to non-attendance, lack of leadership, consensus” $(35,42)$.

Non-participation in group online activities was the major concern. Comments ranged in severity from the simple statement:

Weakness ... the inability of other students to contribute to weekly group tasks $(100,42)$

through concern

Everyone needs to be involved for groups to work well. It is very frustrating if you are trying to do all the set work but are not getting any feedback. $(37,42)$

to feelings of inequity

We feel used by those people who never/seldom contribute, but are still able to follow group and class discussion. If you were on campus, you don't get to hear what goes on in a lecture/tutorial unless you attend! $(108,42)$

Time gets wasted and motivation decreases when you are in a group where there is one member not pulling their weight and/or not presenting relevant work or 
work up to standard. The rest of the group has to carry these people, which is grossly unfair $(109,42)$.

These comments clearly highlight the difficulties arising from non-participation. However, the point to be taken from the analysis is that of group variability rather than individual non-participation. Some students were members of a group they saw as highly effective, while others were deeply concerned with the level of participation. Differences in group participation result from variance in group composition entry variables (Carabajal, LaPointe, and Gunawardena, 2003). In the context of this research, four of the five entry variables noted by Carabajal, LaPointe and Gunawardena, will be very nearly constant across all groups - group size, task types, behavioural setting, and culture. Groups are all a similar size; they are undertaking the same tasks over the same timeframe; they are involved in the same educational setting; and, members share similar cultural backgrounds. The remaining variable - member characteristics/attitudes/skills must therefore account for a large amount of the variation seen between groups. Developing understanding of the ways in which individual attributes operate to impact on participation offers fertile ground for future research and the opportunity to develop further knowledge of group development.

\section{Conclusion}

The work reported here adds to our understanding of the interaction that occurs between students in online learning environments. Evident in the data is that every mode of communication has some value for learning and affective support, although small groups and the whole class discussion space featured prominently. Students clearly differentiated between their use of small groups and the whole class as discussion spaces for learning and for affective support. For nearly all students, small groups had value for both communicative functions, while the value of the whole class space in terms of affective support was considerably lessened. Despite the value of small groups, students saw non-participation in groups as a major issue with implications for workload, the value of learning activities, and motivation to continue engagement with the group.

This study provides insights that may be useful to many involved in distance education, including lecturers and course and programme designers. It also supports the need for ongoing exploration of the nature of group processes in small online learning groups and investigation of differential student responses to the range of contexts for interaction available in online distance education courses.

\section{References}

Anderson, B. (2004). Dimensions of learning and support in an online community. Open Learning, 19(2), 183 - 190.

Anderson, T., and Garrison, D. R. (1998). Learning in a networked world: New roles and responsibilities. In C. C. Gibson (Ed.), Distance learners in higher education (p. 97-112). Madison, WI: Atwood.

Angeli, C., Valanides, N., and Bonk, C. J. (2003). Communication in a Web-based Conferencing System: The quality of computer mediated interactions. British Journal of Educational Technology, 34(1), 31 - 43. 
Bonk, C. J., and Cunningham, D. J. (1998). Searching for learner-centred, constructivist and sociocultural components of collaborative educational learning tools. In C. J. Bonk and K. S. King (Eds.) Electronic Collaborators: Learner-centred technologies for literacy, apprenticeship, and discourse (p. 296-306). Mahwah, NJ.: Lawrence Erlbaum.

Bruffee, K. A. (1999). Collaborative Learning: Higher education, interdependence, and the authority of knowledge (2nd ed.). Baltimore, MA.: John Hopkins University Press.

Carabajal, K., LaPointe, D., and Gunawardena, C. N. (2003). Group development in online learning communities. In M. Moore and W. G. Anderson (Eds.) Handbook of Distance Education (p. 217-234). Mahwah, NJ.: Lawrence Erlbaum Associates.

Fahy, P., Crawford, G., and Ally, M. (2001). Patterns of interaction in a computer conference transcript. International Review of Research in Open and Distance Learning, 2(1). Retrieved August 23, 2001, from: http://www.irrodl.org/content/v2.1/fahy.pdf

Garrison, D. R., Anderson, T., and Archer, W. (2001). Critical thinking, cognitive presence and computer conferencing in distance education. The American Journal of Distance Education, 15(1), 1 - 17.

Gee, J. P. (1999). An introduction to discourse analysis. London: Routledge.

Gunawardena, C. N., Lowe, C. A., and Anderson, T. (1997). Analysis of a global online debate and the development of an interaction analysis model for examining social construction of knowledge in computer conferencing. Journal of Educational Computing Research, 17(4), $397-431$.

Howell-Richardson, C., and Mellar, H. (1996). A methodology for the analysis of patterns of participation within computer mediated communications courses. Instructional Science, 24(1), $47-69$.

Jonassen, D., Davidson, M., Collins, M. P., J, C., and Bannan Haag, B. (1995). Constructivism and computer-mediated communication in distance education. The American Journal of Distance Education, 9(2), 7 - 26.

Pavitt, C., and Johnston, K. (1999). An examination of the coherence of group discussions. Communications Research, 26(3), 303 - 321.

Rose, M. A. (2004). Comparing productive online dialogue in two group styles: Cooperative and collaborative. The American Journal of Distance Education, 18(2), 73 - 88.

Rovai, A. P. (2002). Sense of community, perceived cognitive learning and persistence in asynchronous learning networks. The Internet and Higher Education, 4, 319 - 332.

Ryan, Y. (2001). The provision of learner support services online. In G. M. Farrell (Ed.) The changing faces of virtual education (p. 71-94). Vancouver, BC.: The Commonwealth of Learning. 
Wrightson, T. (1998). Distance Education in Action: The Northern Integrated Teacher Education project in Uganda. Cambridge, England: International Extension College.

Yorke, M. (2004). Retention, persistence and success in on-campus higher education, and their enhancement in open and distance learning. Open Learning, 19(1), 19 - 32. 